\title{
KINETIC PARAMETERS OF TORREFACTION PROCESS OF ALTERNATIVE FUEL PRODUCED FROM MUNICIPAL SOLID WASTE AND CHARACTERISTIC OF CARBONIZED REFUSE DERIVED FUEL
}

\author{
Paweł Stępień *,1 and Andrzej Białowiec 1,2 \\ ${ }^{1}$ Wrocław University of Environmental and Life Sciences, Faculty of Life Sciences and Technology, Institute of Agricultural \\ Engineering, 37/41 Chełmońskiego Str., 51-630 Wrocław, Poland \\ ${ }^{2}$ Ekopartner-Recykling sp. z o.o., 3 Zielona Str., 59-300 Lubin, Poland
}

Article Info:
Received:
17 January 2018
Revised:
17 June 2018
Accepted:
31 August 2018
Available online:
14 September 2018
Keywords:
Torrefaction
RDF
Kinetic parameters
Carbonized refuse derived fuel

\section{INTRODUCTION}

Waste conversion for energy purposes offers an effective way of recycling. This approach is very important in times of increased energy demand and the requirements of waste utilization and recycling. One of the ways to maximize the production of electricity and heat from waste is to produce Refuse Derived Fuel (RDF) and direct it for later thermal recovery and/or recycling.

$\mathrm{RDF}$ is a converted waste material that is generated by mechanical treatment (grinding, sorting) of combustible municipal and industrial wastes, including primarily plastics, paper and wood. RDF is most often used for the production of electricity and heat (Dalai et al., 2009; Preston and Kollberg 2016).

In Poland, municipal wastes are sent first to the Regional Municipal Waste Treatment Plant or to a waste incineration plant. At the Regional Municipal Waste Treatment Plant waste is subjected to mechanical biological treatment. The waste stream in the plant is divided into two fractions using a sieve with a mesh size of $80 \mathrm{~mm}$. From the over-sieve fraction, materials that can be recycled are selected, and then unselected waste is converted into alternative fuel (RDF) for a waste incineration plant or cement plant. The under-sieve fraction undergoes a biostabilization process. After this process, the obtained stabilized waste is sieved on a $20 \mathrm{~mm}$ sieve. The obtained over-sieve fraction is most often disposed at the landfill, and the fine fraction is used as a material for landfill covering (Pietryszyn and Primus 2015, SPC report 2015, Kinitz 2014).

At present, there are 127 Regional Municipal Waste Treatment Facilities in Poland, and their total capacity is 8164 thousand Mg per year. RDF incineration plants can be divided into two types: cement plants and waste incineration plants. 9 cement plants in Poland have the total capacity of 1200 thousand Mg of RDF per year. In Poland, waste incinerators are currently in the initial stages of com- 
missioning or in the final phase of construction. Ultimately, 7 incineration plants will operate in the area of Poland, with a total capacity of 1014 thousand Mg per year (Pietryszun and Primus, 2015).

The total mass of the produced RDF amounts 2 million $\mathrm{Mg}$ per year. The RDF produced in Poland is characterized by the following properties: moisture content fluctuates from $3.20 \%$ to $24.80 \%$, ash content from 11.00 to $24.30 \%$ d.m., sulphur content from $0.12 \%$ to $0.76 \%$ d.m.. Higher

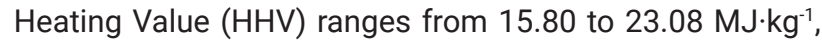
is Low Heating Value (LHV) from 14.53 to $21.59 \mathrm{MJ}^{\mathrm{kg}}{ }^{-1}$. The RDF is also characterized by high heterogeneity, which adversely affects the possibility of maintaining constant fuel properties (Ahn et al., 2013; Nowak and Szul, 2016).

RDFs are used for energy and heat production in cement plants and waste incineration plants with a total capacity of 1.996 thousand $\mathrm{Mg}$ per year (Krawczyk and Szczygief 2013; Kinitz N., 2014). It should be noted that the total capacity of RDF utilization installations is two times smaller than the estimated annual volume of RDF produced. This situation results in a decrease in costs for wastes utilization in a thermal processing plant and increase in the requirements for the quality of RDF produced by the MBPs. At present, the essential parameters to be met by RDF are: calorific value $>20 \mathrm{MJ} \cdot \mathrm{kg}^{-1}$, moisture content $<15 \%$, heavy metal content $<2500 \mathrm{mg} / \mathrm{kg}$, chlorine content $<1 \%$, sulphur content $<1.5 \%$, and ash $<15 \%$. In addition, the RDF should have a granularity of less than $40 \mathrm{~mm}$ and be a homogeneous mixture (Hryb and Biegańska, 2013).

Torrefaction also called roasting, high-temperature drying, low-temperature pyrolysis could be a helpful solution for overcoming problems with RDF qualitative requirements. Torrefaction is a thermo-chemical process, with following characteristics: temperature $200-300^{\circ} \mathrm{C}$, heating rate $<50^{\circ} \mathrm{C} \cdot \mathrm{min}^{-1}$, residence time $<60$ minutes, no oxygen, atmospheric pressure (Tumuluru et al., 2011). Five process phases can be distinguished: pre-heat, pre-drying, drying and transient heating, torrefaction, cooling of the product (Bergman et al., 2005). As a result of the process, two products are obtained: biochar and torrefaction gas one with a mass balance of $70-80 \%$ and $23-30 \%$ respectively. The solid product is called biocarbon when agricultural or forestry biomass is used as a substrate. For other substrates, it is called carbonate or biochar (Malińska, 2015). The gas product is referred to as a tor-gas (Bergman et al., 2005).

The solid product resulting from the processing of agricultural or forestry biomass is characterized by:

- High energy density. Processed biomass contains 70$80 \%$ of the initial mass and $80-90 \%$ of initial energy (Tumuluru et al., 2010);

- Decrease in moisture content. After the torrefaction process, the moisture content of the obtained product is approximately $1-2 \%$ mass (Tumuluru et al., 2010);

- Hydrophobic properties. Processed biomass manifests high hydrophobicity. Maximum water uptake is 1-6\% (Tumuluru et al., 2010) (e.g. water content in unprocessed wood biomass ranges from 12 to $22 \%$, bark from 45 to $55 \%$ (Kordylewski et al., 2008));

- Increased carbon content. The concentration of carbon in the structure of the compound results in increased biocarbon reduction properties (Bergman, 2005);

- Reduction of oxygen and hydrogen. The O/C and H/C ratios are reduced, resulting in an increase in the attractiveness of biocarbon as a substrate for the gasification process (Prins, 2005);

- Better milling properties. Due to the depolymerisation of cellulose fibres, lignin and hemicellulose biochar grinding requires less energy since the structure and form of the particulate matter is similar to carbon (Bergman et al., 2004).

Due to the above, torrefaction process may be a good way to increase the fuel properties of RDF. However, this process has not been characterized or understood deeply. This paper presents the characteristics of the thermal decomposition of RDF using thermogravimetric analysis (TGA). Using the qualitative interpretation method of the TGA curve, changes in the mass decrease pattern of the sample under linear temperature increase were observed, whereby a comparison of the mass drop within temperature range with the values given in literature of the individual RDF components was conducted. The quantitative interpretation of the TGA allowed for the determination of kinetic parameters such as the reaction rate constant and activation energy. These parameters are indispensable in the torrefaction modelling process.

RDF and produced carbonates are characterized in terms of fuel properties. The conducted analysis allowed to determine the suitability of the torrefaction as an alternative fuels valorisation process.

\section{MATERIAL AND METHOD}

\subsection{RDF used in the study}

The RDF used in the study was taken from a mechanical-biological waste treatment facility with the status of a regional waste treatment plant. The facility is located in the village of Gać, Poland (in the region of Lower Silesia). The process of production RDF from municipal solid waste is presented in Figure 1.

A general $250 \mathrm{~kg}$ sample was taken from RDF's production line and then a laboratory sample of $5 \mathrm{~kg}$ was separated from the general sample by quartering (PN-Z-15006:1993). In order to homogenize the material (RDF and RDFs), it was ground to particle size $\leq 0.425 \mathrm{~mm}$ with the use of the LMN 100 knife mill. The material to be tested was prepared in the way presented below.

\subsection{Carbonized Refuse Derived Fuel production method}

The biochar, previously referred to as Carbonized Refuse Derived Fuel (CRDF) (Białowiec et al., 2017) was obtained by means of the SNOL 8.1/1100 muffle furnace (Figure 2). CRDF samples were generated under the following conditions:

- Temperature range from 200 to $300^{\circ} \mathrm{C}$ (temperature interval of $20^{\circ} \mathrm{C}$ );

- Retention time: 20, 40, 60 minutes for each temperature; 


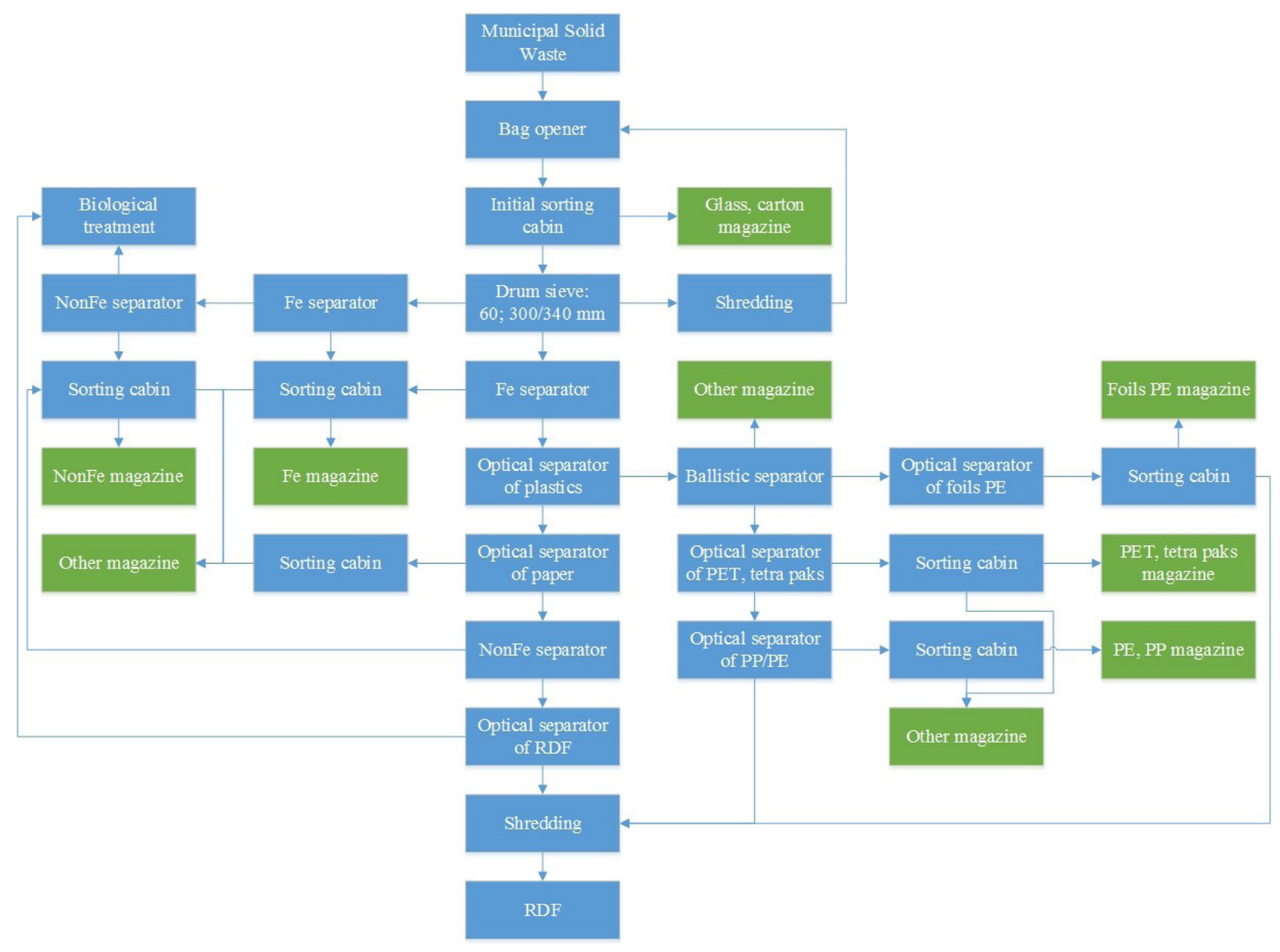

FIGURE 1: The configuration of RDF production lines at MBT plant in Gać.

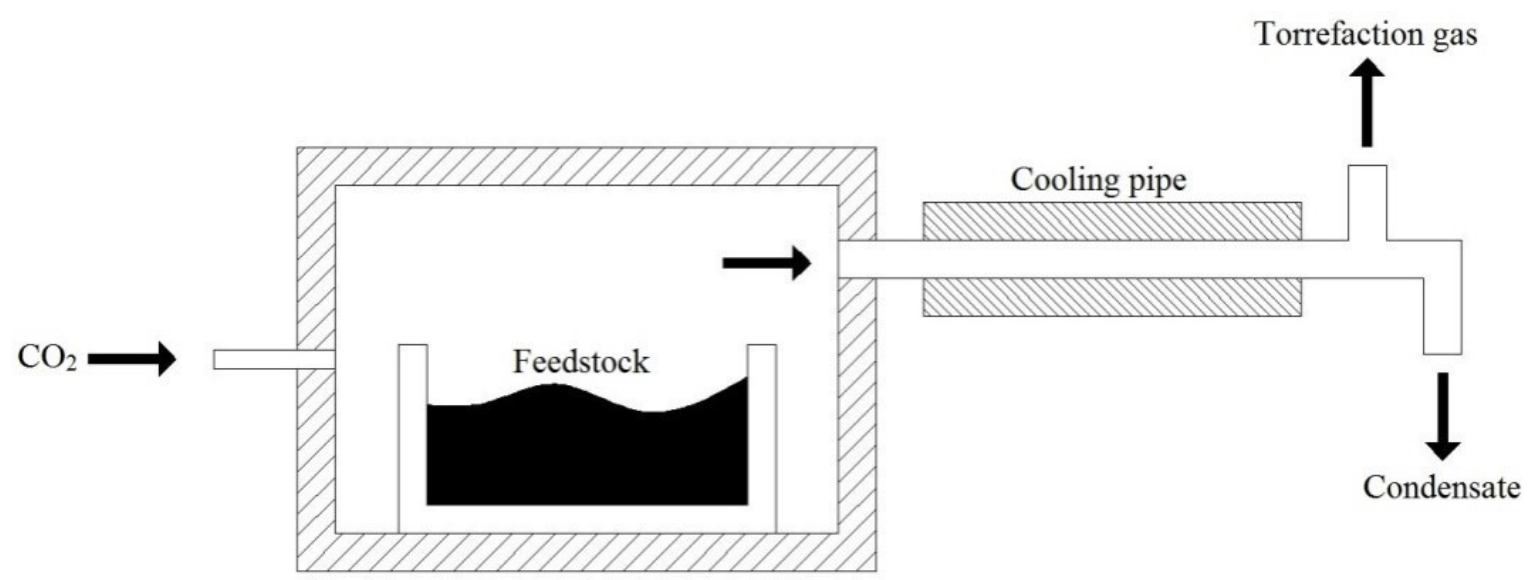

FIGURE 2: Schematic figure of the experimental set-up of CRDF generation.

- Temperature rise: $50^{\circ} \mathrm{C} \cdot \mathrm{min}^{-1}$ (maximum heating rate);

- Used gas: carbon dioxide;

- Gas flow: $10 \mathrm{dm}^{3} \cdot \mathrm{h}^{-1}$.

The heating of the reactor was commenced 5 minutes after gas introduction into the device began. Carbon dioxide was cut off when the temperature inside the reactor during the cooling phase reached $100^{\circ} \mathrm{C}$ (Madanayake et al., 2016).

\subsection{Physical and chemical analysis of RDF and CRDF}

The RDF and generated CRDF from torrefaction were tested for:

- Morphological composition (only RDF) in accordance with Malinowski and Wolny-Koładka (2012);

- Moisture content by means of the KBC65W laboratory dryer in accordance with the PN-EN 14346:2011 stan- 
dard;

- Content of organic matter by means of the SNOL $8.1 / 1100$ muffle furnace in accordance with the PN-EN 15169:2011 standard;

- Combustible and non-combustible content by means of the SNOL 8.1/1100 muffle furnace in accordance with the PN-Z-15008-04:1993 standard;

- Volatile content by means of the SNOL 8.1/1100 muffle furnace in accordance with the PN-G-04516:1998 standard;

- Higher heating value by means of the IKA C2000 Basic calorimeter in accordance with the PN-G-04513:1981 standard.

Each of the designations was repeated 3 times.

\subsection{Thermogravimetric analysis (TGA) of RDF}

The thermogravimetric analysis was carried out by means of the Czylok RST 40·200/110P stand-mounted tubular furnace (Figure 3).

The study used the method of qualitative and quantitative interpolation of the TGA curve. The qualitative method allows for determining the mass deviations of the sample to be tested at a set temperature. By this analysis, the distribution of particular chemical compounds that build up the sample may be observed. A quantitative method allows for determining the kinetic parameters of the process. The measurement is based on accurate determination of the mass change and its rate at particular temperatures.

The first method was carried out under the following conditions:

- Temperature from 10 to $850^{\circ} \mathrm{C}$;

- Temperature rise: $10^{\circ} \mathrm{C} \cdot \mathrm{min}^{-1}$ (maximum heating rate);

- Used gas: carbon dioxide;

- Gas flow: $10 \mathrm{dm}^{3} \cdot \mathrm{h}^{-1}$.

The second method was carried out under the follow-

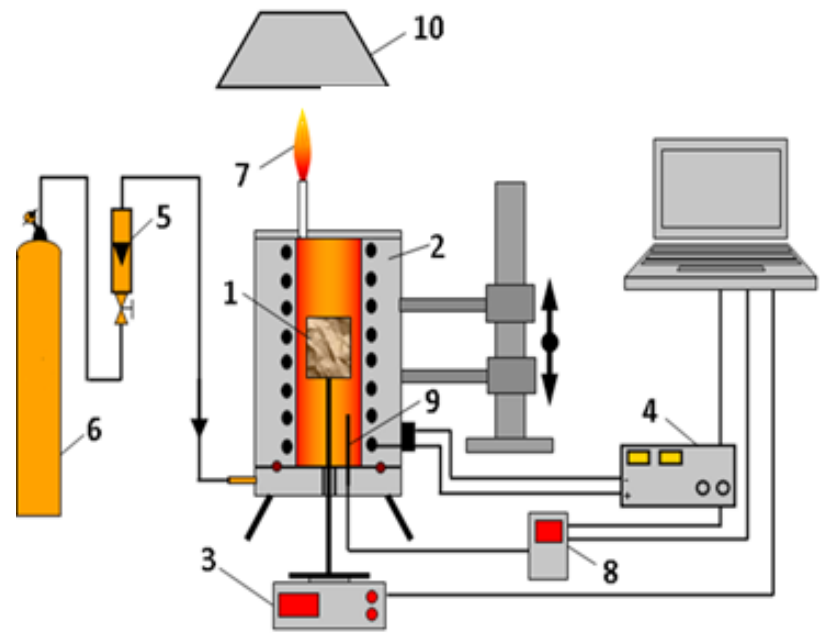

FIGURE 3: Reactor set-up: 1 - a vessel filled with solid fuel sample, 2 - electrically heated reactor, 3 - electronic balance, 4 - electric power feeder (regulator), 5 - rotameter, 6 - bottle with carbon dioxide, 7 - gaseous products of pyrolysis/torrefaction process, 8 - temperature indicator, 9 - thermocouple, 10 - exhaust chimney. ing conditions:

- Temperature range from 200 to $300^{\circ} \mathrm{C}$ (temperature interval of $20^{\circ} \mathrm{C}$ );

- Retention time: 60 minutes for each temperature;

- Used gas: carbon dioxide;

- Gas flow: $10 \mathrm{dm}^{3} \cdot \mathrm{h}^{-1}$.

Based on TGA results, the reaction rate and activation energy within the torrefaction temperature range was calculated by Statistica 13.1 software. The reaction constant rate of the thermal transformation of the material was calculated on the basis of a first-order reaction (Eq. 1, Eq. 2) (Bates et al., 2012):

$M_{S}=M_{S}^{0} \cdot e^{-k \cdot t}$

$\ln \frac{M_{S}^{0}}{M_{S}}=k \cdot t$

where: $M_{S}^{0}$ is initial mass, $g, M_{S}$ is mass per unit, $g, k$ is reaction rate constant, $1 \cdot \mathrm{s}^{-1}, t$ is time, $s$.

The Arrhenius equation (Eq. 3) (Bates et al., 2012) represents the dependence of the reaction constant rate $k$ on the temperature $T$ :

$k(T)=A \cdot \exp -\frac{E_{a}}{R \cdot T}$

The logarithmic form of the equation (Eq. 3) is shown below:

$\ln k(T)=\ln A-\frac{E_{a}}{R \cdot T}$

where: $R$ is universal gas constant, $8.314 \mathrm{~J} \cdot(\mathrm{mol} \cdot \mathrm{K})^{-1}, T$ is temperature, $\mathrm{K}, A$ is a pre-exponential factor, $1 \cdot \mathrm{s}^{-1}, E_{a}$ is activation energy, $\mathrm{J} \cdot \mathrm{mol}-1, k$ is reaction constant rate, $1 \cdot \mathrm{s}^{-1}$.

Using the Arrhenius equation, activation energy can be calculated by means of the reaction constant rate. $\operatorname{Ln}(\mathrm{k})$ is a linear function of 1·T-1 (Eq. 5) (Soria-Verdugo, 2015).

$y=a \cdot x+b$

where:

$y=\ln (k)$

$b=\ln A$,

$a=\frac{E_{a}}{R}$,

$x=1 \cdot T$.

\section{RESULTS AND DISCUSSION}

\subsection{Results of the physical and chemical analysis of the substrate}

RDF morphological composition is shown in Table 1.

The percentage share of highly calorific waste (plastics, paper, wood, textiles) was $54.3 \%$. This value is low, but lies within the lower range of values given in literature, where the proportion of highly calorific waste was from $53.2 \%$ to $100 \%$ (Seo i in. 2010; Miskolczi i in., 2011; Kara, 2012; Kruger i in., 2014; Akdag i in., 2016; Çepolioğullar Ö i in., 2016).

The average results of the physical and chemical analyses of RDF are presented in Table 2.

Moisture content in the RDF was $17.31 \%$. This value is within the upper limit of the moisture content in RDF. The 
TABLE 1: The average morphological composition $(\mathrm{N}=3)$ of the analysed RDF.

\begin{tabular}{|c|c|}
\hline Waste group & Share of a waste group (\%) \\
\hline Plastics & 30.3 \\
\hline Paper & 11.3 \\
\hline Wood & 10.5 \\
\hline Composite waste & 8.3 \\
\hline Rubber & 5.6 \\
\hline Textiles & 2.2 \\
\hline Metal & 0.1 \\
\hline Glass & 0.1 \\
\hline Kitchen and garden waste & 0.1 \\
\hline Other unidentified waste and mineral waste & 31.6 \\
\hline
\end{tabular}

TABLE 2: The average ( \pm SD - standard deviation) values of physical and chemical properties of the analysed alternative fuel.

\begin{tabular}{l|c} 
Sample & Alternative fuel \\
\hline Moisture (\%) & $17.31 \pm 4.48$ \\
\hline Organic matter content (\%) & $85.80 \pm 15.32$ \\
\hline Volatile content (\%) & $85.13 \pm 1.04$ \\
\hline Combustible content (\%) & $86.75 \pm 1.82$ \\
\hline Ash (\%) & $13.25 \pm 1.82$ \\
\hline High calorific value $\left(\mathrm{MJ} \cdot \mathrm{kg}^{-1}\right)$ & $25.41 \pm 1.58$ \\
\hline
\end{tabular}

moisture content reported in the literature ranges from $1.6 \%$ to $17.4 \%$ (Akdag et al., 2016; Edo et al., 2016; Manya et al., 2015; Seo et al., 2010; Singh et al., 2011).

Analysing the results of the content of organic matter and the content of combustible components, it must be noted that RDF is mostly built of organic materials that break down to $550^{\circ} \mathrm{C}$. This is reflected in the morphological composition of the alternative fuel, which consists mainly of materials (plastics and wood) that undergo decomposition at temperatures of $550^{\circ} \mathrm{C}$ (Robinson et al., 2016). The residual matter is ash, whose average value in the analysed material was $13.25 \%$. The ash content in RDF ranges from 8.64\% to 26.29\% (Ahn et al., 2013; Akdag et al., 2015; Çepolioğullar et al., 2016; Miskolczi et al., 2011; Seo et al., 2010; Singh et al., 2012).

The determined high calorific value was higher than

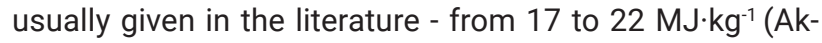
dag et al., 2016; Çepolioğullar Ö et al., 2016; Whyte et al., 2015).

\subsection{Results of a thermogravimetric analysis}

During the thermogravimetric analysis, two weight drops were observed. The mass decreases occurred between $210^{\circ} \mathrm{C}$ and $380^{\circ} \mathrm{C}$, and between $380^{\circ} \mathrm{C}$ and $730^{\circ} \mathrm{C}$. Material transformation followed one by one (Figure 4).

The first thermal decomposition may be linked of hemicellulose and cellulose breakdown. The temperature ranges of the thermal decomposition of these two compounds are as follows: hemi-cellulose $220-315^{\circ} \mathrm{C}$, cellulose 315-370 ${ }^{\circ} \mathrm{C}$ (Akdeg et al. 2016; Carrier et al., 2011; Lu et al., 2012). The second peak may be linked to the decomposition of plastics. Degradation of these materials begins above $400^{\circ} \mathrm{C}$ (Robinson et al., 2016; Sanchez-Silva et al., 2012; Stępień et al., 2017).

An equation (1) was used to calculate reaction constant rates and activation energies for temperatures within the range of $200-300^{\circ} \mathrm{C}$ (Table 3 ).

The estimated activation energy was $3.71 \mathrm{~kJ} \cdot \mathrm{mol}^{-1}$. Literature review showed that activation energy for RDF depends on temperature ranges: between $240-380^{\circ} \mathrm{C}$ and between $250-370^{\circ} \mathrm{C}$. The values obtained by Singh et al. (2012) and Grammelis et al. (2007) were much higher and were 97.8 and $121 \mathrm{~kJ} \cdot \mathrm{mol}^{-1}$, respectively.

\subsection{Results of the physical and chemical analysis of the CRDF}

The average results of the physical and chemical analyses of carbonized refuse derived fuel are presented on 3D

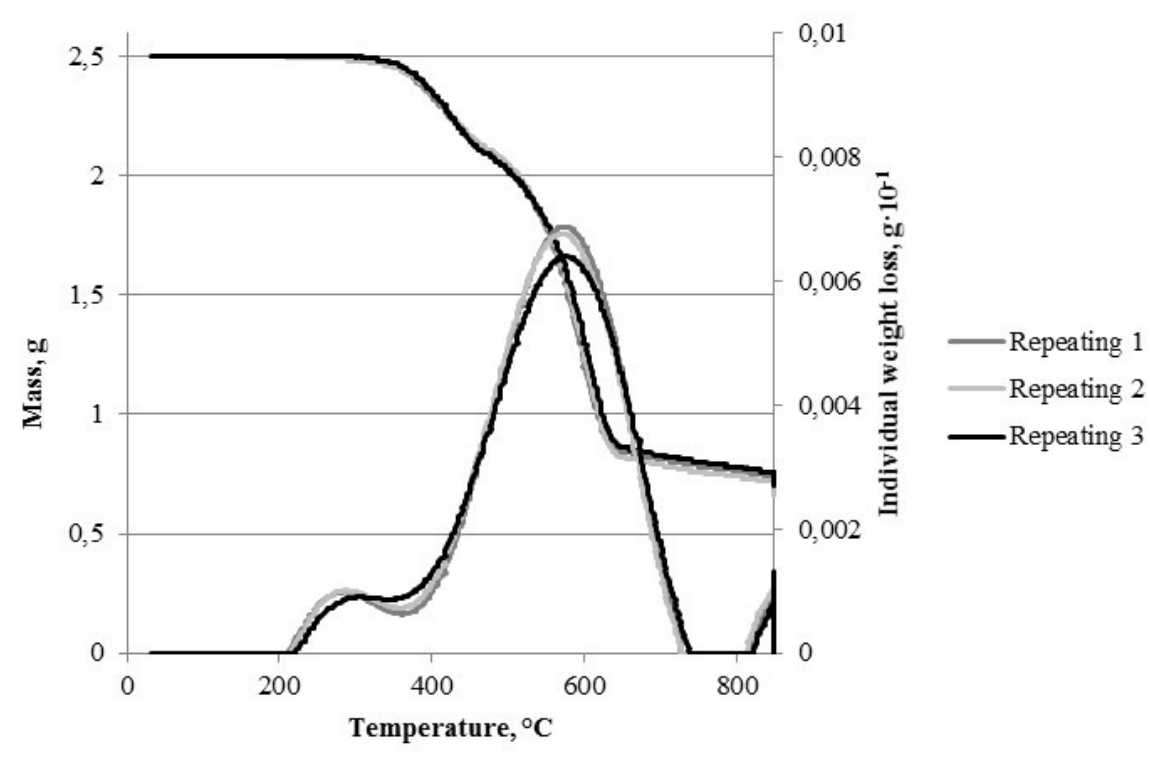

FIGURE 4: DTG and TGA characteristics of RDF. 
charts with spline interpolation (Figures 5-10).

Moisture content for untreated RDF was $17.31 \%$. The residual water content in carbonates was the smallest at temperature $200^{\circ} \mathrm{C}$ and retention time 20 minutes. In that case, the moisture decreased to $0.13 \%$ (Figure 5). The moisture content increased to $1.27 \%$ along with the increase of the temperature and retention time of the torrefaction process. The studies conducted by Nobre et al., (2016), found that the torrefaction process had a positive effect on the moisture content reduction. They indicated that the content of water $6.02 \%$ in the raw material dropped to $2.23 \%$ during torrefaction at $300^{\circ} \mathrm{C}$ for 30 minutes.

The contents of organic matter (Figure 6), combustible (Figure 7) and volatile components (Figure 8) were similar. This was correlated with characteristics of thermal decomposition of materials present in RDF, including plastic and lingo-cellulosic compounds. These materials undergo thermal degradation of up to $550^{\circ} \mathrm{C}$. The higher content of combustible components in relation to the organic matter is associated with a high temperature distribution of volatiles (Lu et al., 2012, Robinson et al., 2016). The content of organic matter, combustible and volatile components in relation to unprocessed biomass was reduced by $6 \%, 7 \%$, and $7 \%$, respectively. These values are low compared to the results obtained by Nobre et al. (2016), where the decrease in the volatiles amounted to $22 \%$ at $300^{\circ} \mathrm{C}$ torrefaction with 30 minutes residence time. Such a large difference may be due to the different morphological composition of the tested samples. The highest residual organic matter has been found for temperature range from 240 to $260^{\circ} \mathrm{C}$, and residence time 40 minutes (Figure 6 ). The tendency of combustibles content decrease with the increase in torrefaction temperature, for all tested residence times, was observed (Figure 7). A similar relationship was found for volatiles content, with the highest value for a variant with temperature $200^{\circ} \mathrm{C}$, and 60 minute of residence time (Figure 8).

The ash content in CRDF is indirectly related to the increase in temperature and residence time that affects the sample gasification. It should be noted that ash content in carbonate increased to over $23 \%$ (Figure 9). The raw material was characterized by the ash content of $13 \%$. The maximum ash content in torrefied materials was lower compared to RDF. The maximum value of the quoted parameter can be as high as $26 \%$.

The decrease in $\mathrm{HHV}$ is related to the ash content increase and the gasification of the volatile component. According to the principles of torrefaction, the substrate should have a low content of inert parts, because after the process, when partial degassing of the volatiles occurs, the mass ratio of the ash to the entire mass of the particle increases (Tumuluru et al., 2011). In the case of RDF torrefaction, the optimum value of the process was $260^{\circ} \mathrm{C}$ with 20 minutes of residence time. For this torrefaction parameters, the average value of $\mathrm{HHV}$ was $26.22 \mathrm{MJ} \cdot \mathrm{kg}^{-1}$. Comparing this value with the average HHV of unprocessed material, the obtained value was higher by 0.81 $\mathrm{MJ} \cdot \mathrm{kg}^{-1}$.

The observed tendency of HHV decrease along with the increase in temperature and retention time was also reflected in the research carried out by Nobre et al. (2016), in which the HHV heat decreased from 17.68 to 15.70 $\mathrm{MJ} \cdot \mathrm{kg}^{-1}$.

Due to the low content of lingo-cellulosic compounds in the waste, they could have reacted completely at a temperature lower than $300^{\circ} \mathrm{C}$. The main component of RDF were plastics, whose distribution starts at $400^{\circ} \mathrm{C}$ (Robinson et al., 2016). The complete conversion of the lignocellulose parts caused a rise in the ash content, which had an impact on the ash presence in the sample. The final effect was that the higher ash content resulted in the decrease in $\mathrm{HHV}$.

Table 4 shows the comparison of raw material with the obtained CRDF's.

\section{CONCLUSIONS}

The TGA analysis has shown that one of the materials groups contained in RDF is decomposing within the temperature range of the torrefaction process. The observed transformation was attributed to the decomposition of cellulose and hemicellulose which build wood and paper in RDF. The calculated activation energy in the temperature range of 200 to $300^{\circ} \mathrm{C}$ was $3.71 \mathrm{~kJ} \cdot \mathrm{mol}^{-1}$.

Thetorrefaction process hasapositive effect on reducing the moisture content. Moisture decreased from $17 \%$ to $1 \%$.

As the temperature and retention of the torrefaction process increased, the material degassed significantly, resulting in an increase in ash content in the product. This parameter unfavourably influences the HHV.

The highest HHV of CRDF was achieved for temperature $260^{\circ} \mathrm{C}$, and residence time 20 minutes.

Scientific research on the torrefaction of RDF is still at an early stage and needs to be further developed in order to accurately characterize the process and the obtained products.

TABLE 3: Reaction constant rate and activation energy

\begin{tabular}{|c|c|c|c|c|c|c|}
\hline $\mathrm{T}, \mathrm{K}$ & $k, 1 \cdot s^{-1}$ & $\mathbf{R}^{2}$ & $1 \cdot T^{-1}$ & $\ln (k), 1 \cdot s^{-1}$ & $\mathrm{E}, \mathrm{J} \cdot \mathrm{mol}^{-1}$ & $\mathbf{R}^{2}$ \\
\hline 473 & $1.41 \mathrm{E}-05$ & 0.89 & $2.11 \mathrm{E}-03$ & $-1.12 E+01$ & \multirow{6}{*}{$3.71 \mathrm{E}+03$} & \multirow{6}{*}{0.55} \\
\hline 493 & $1.44 \mathrm{E}-05$ & 0.77 & $2.03 \mathrm{E}-03$ & $-1.11 E+01$ & & \\
\hline 513 & $1.47 \mathrm{E}-05$ & 0.78 & $1.95 \mathrm{E}-03$ & $-1.11 E+01$ & & \\
\hline 533 & 1.37E-05 & 0.78 & $1.88 \mathrm{E}-03$ & $-1.12 \mathrm{E}+01$ & & \\
\hline 553 & $1.66 \mathrm{E}-05$ & 0.80 & $1.81 \mathrm{E}-03$ & $-1.10 \mathrm{E}+01$ & & \\
\hline 573 & $1.66 \mathrm{E}-05$ & 0.67 & $1.75 \mathrm{E}-03$ & $-1.10 \mathrm{E}+01$ & & \\
\hline
\end{tabular}



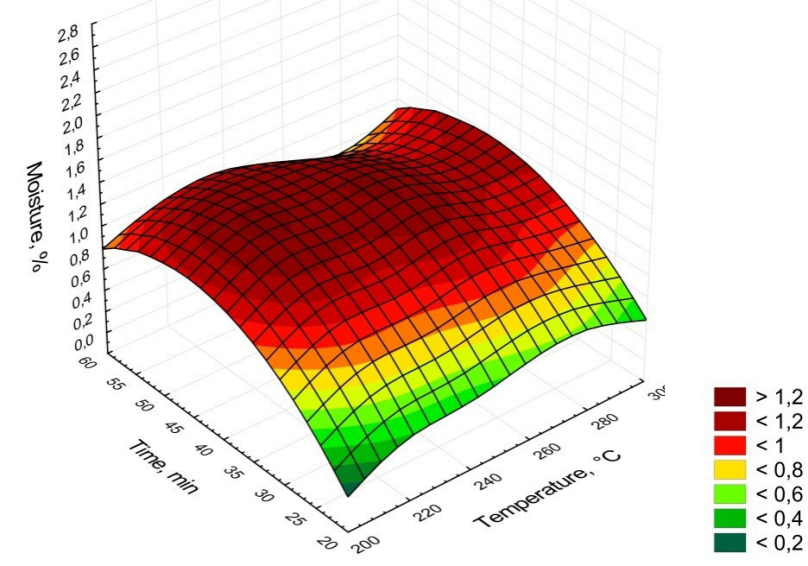

FIGURE 5: Effect of torrefaction temperature and retention time on the moisture content in CRDF.

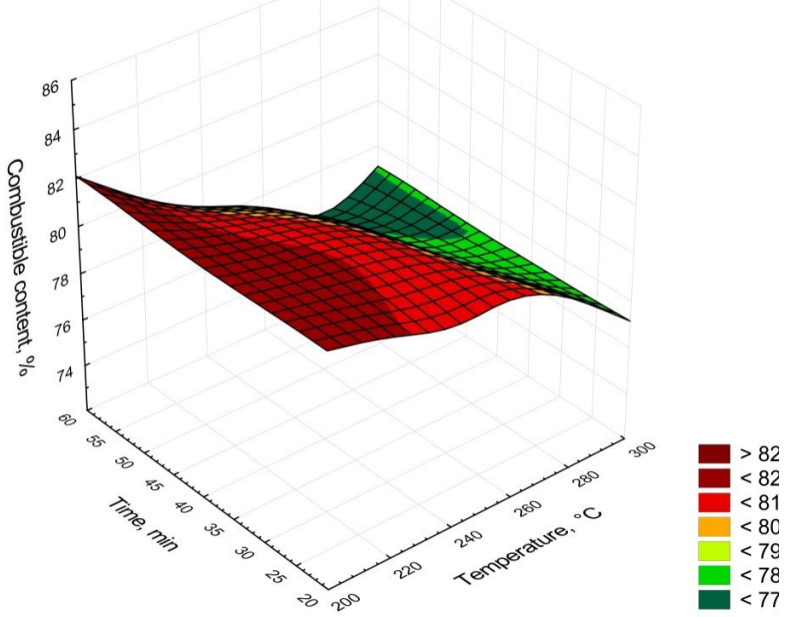

FIGURE 7: Effect of torrefaction temperature and retention time on the combustible content in CRDF.

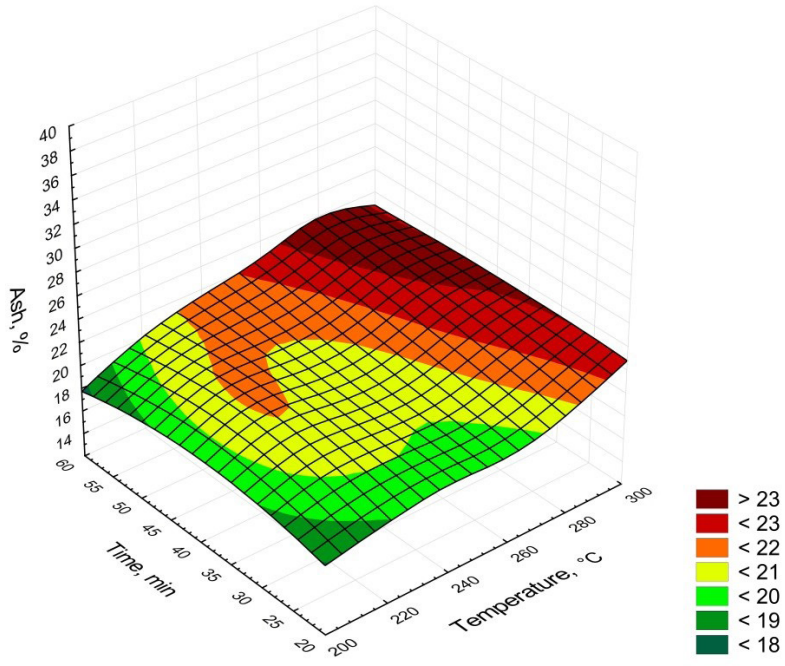

FIGURE 9: Effect of torrefaction temperature and retention time on the ash content of CRDF.

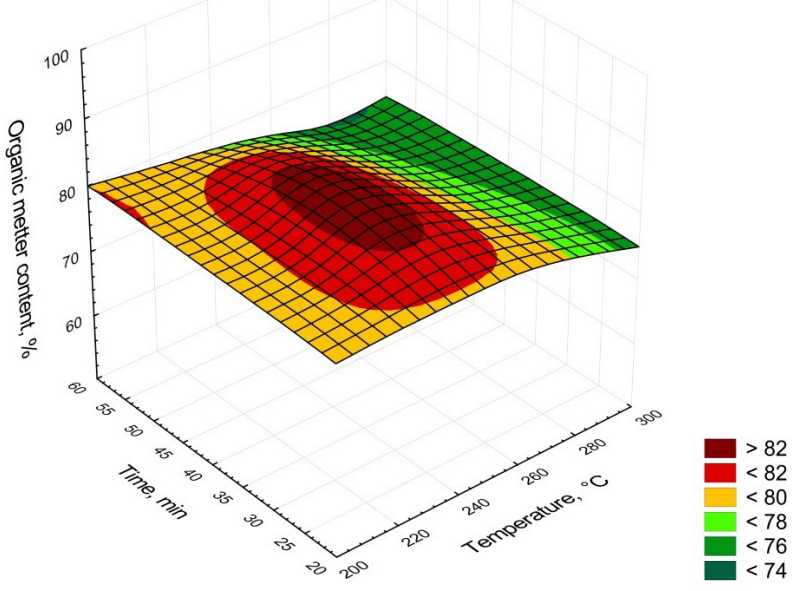

FIGURE 6: Effect of torrefaction temperature and retention time on the organic matter content in CRDF.

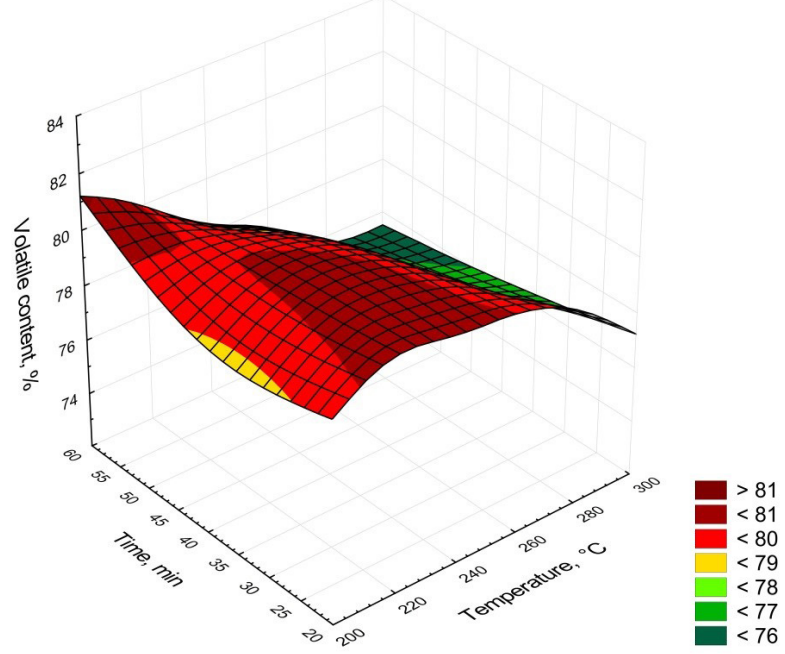

FIGURE 8: Effect of temperature and retention time on the volatile content in CRDF.

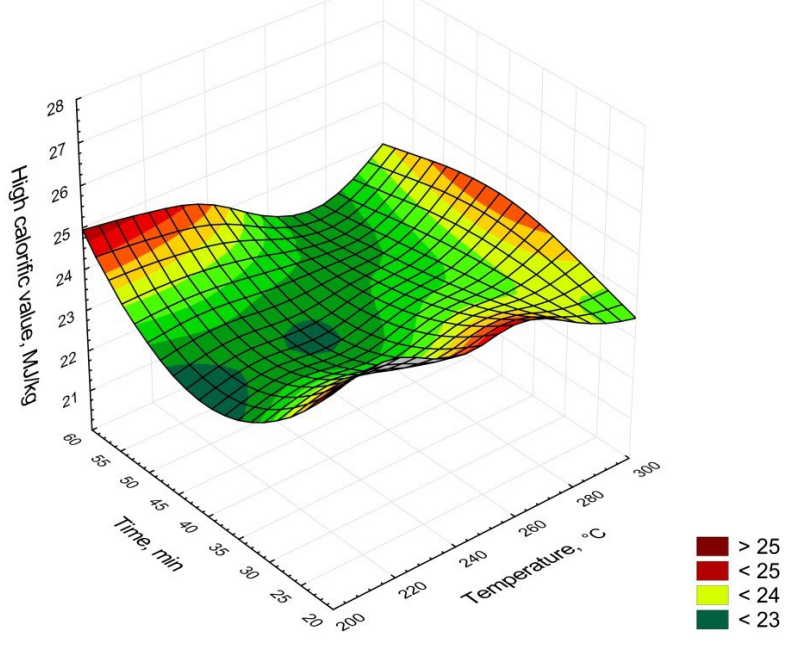

FIGURE 10: Effect of torrefaction temperature and retention time on the HHV of CRDF. 
TABLE 4: The average ( \pm SD - standard deviation) values of physical and chemical properties of the analysed alternative fuel and CRDF's.

\begin{tabular}{|c|c|c|c|c|c|c|c|}
\hline \multicolumn{2}{|c|}{ Sample } & Moisture (\%) & $\begin{array}{l}\text { Organic matter } \\
\text { content }(\%)\end{array}$ & $\begin{array}{l}\text { Volatile content } \\
\text { (\%) }\end{array}$ & $\begin{array}{l}\text { Combustible } \\
\text { content }(\%)\end{array}$ & Ash (\%) & $\begin{array}{c}\text { High calorific } \\
\text { value }\left(\mathrm{MJ} \cdot \mathbf{k g}^{-1}\right)\end{array}$ \\
\hline \multicolumn{2}{|c|}{ Alternative fuel } & $17.31 \pm 4.48$ & $85.80 \pm 15.32$ & $85.13 \pm 1.04$ & $86.75 \pm 1.82$ & $13.25 \pm 1.82$ & $25.41 \pm 1.58$ \\
\hline \multirow{3}{*}{200} & 20 & $0.08 \pm 0.07$ & $79.33 \pm 0.30$ & $79.29 \pm 0.38$ & $81.95 \pm 0.30$ & $18.04 \pm 0.30$ & $24.94 \pm 0.31$ \\
\hline & 40 & $0.94 \pm 0.07$ & $80.05 \pm 0.89$ & $77.50 \pm 0.57$ & $81.34 \pm 1.00$ & $18.65 \pm 1.00$ & $22.18 \pm 0.49$ \\
\hline & 60 & $0.76 \pm 0.10$ & $80.83 \pm 0.61$ & $82.01 \pm 0.85$ & $82.65 \pm 0.47$ & $17.34 \pm 0.47$ & $25.15 \pm 0.03$ \\
\hline \multirow{3}{*}{220} & 20 & $0.54 \pm 0.05$ & $79.93 \pm 0.49$ & $81.65 \pm 1.10$ & $81.70 \pm 0.47$ & $18.29 \pm 0.7$ & $26.53 \pm 0.38$ \\
\hline & 40 & $1.63 \pm 0.77$ & $73.85 \pm 0.47$ & $80.60 \pm 0.57$ & $80.94 \pm 3.08$ & $24.25 \pm 11.49$ & $23.50 \pm 0.19$ \\
\hline & 60 & $0.97 \pm 0.03$ & $78.42 \pm 0.71$ & $79.90 \pm 0.31$ & $79.69 \pm 0.70$ & $20.30 \pm 0.70$ & $24.64 \pm 0.47$ \\
\hline \multirow{3}{*}{240} & 20 & $0.26 \pm 0.02$ & $77.41 \pm 1.13$ & $79.05 \pm 0.76$ & $78.85 \pm 1.12$ & $21.14 \pm 1.12$ & $23.10 \pm 0.50$ \\
\hline & 40 & $0.80 \pm 0.45$ & $92.41 \pm 0.85$ & $80.84 \pm 0.70$ & $81.49 \pm 0.39$ & $19.01 \pm 0.51$ & $21.98 \pm 0.32$ \\
\hline & 60 & $1.27 \pm 0.08$ & $76.10 \pm 0.35$ & $76.87 \pm 0.67$ & $77.82 \pm 0.27$ & $22.17 \pm 0.27$ & $25.34 \pm 0.29$ \\
\hline \multirow{3}{*}{260} & 20 & $0.55 \pm 0.05$ & $80.45 \pm 0.44$ & $80.27 \pm 0.44$ & $81.79 \pm 0.46$ & $18.20 \pm 0.46$ & $26.22 \pm 0.84$ \\
\hline & 40 & $1.77 \pm 0.14$ & $78.86 \pm 0.60$ & $80.11 \pm 0.27$ & $80.71 \pm 0.60$ & $19.28 \pm 0.60$ & $24.11 \pm 0.31$ \\
\hline & 60 & $0.73 \pm 0.02$ & $76.55 \pm 1.41$ & $78.06 \pm 0.88$ & $78.49 \pm 1.32$ & $21.50 \pm 1.32$ & $22.65 \pm 0.38$ \\
\hline \multirow{3}{*}{280} & 20 & $0.79 \pm 0.01$ & $78.31 \pm 0.27$ & $79.98 \pm 1.07$ & $80.11 \pm 0.28$ & $19.88 \pm 0.28$ & $23.74 \pm 0.31$ \\
\hline & 40 & $0.73 \pm 0.04$ & $73.19 \pm 0.11$ & $75.13 \pm 0.26$ & $75.77 \pm 0.14$ & $24.22 \pm 0.14$ & $22.91 \pm 0.44$ \\
\hline & 60 & $0.37 \pm 0.06$ & $70.62 \pm 0.31$ & $74.09 \pm 0.70$ & $73.30 \pm 0.28$ & $26.69 \pm 0.28$ & $22.26 \pm 1.21$ \\
\hline \multirow{3}{*}{300} & 20 & $0.25 \pm 0.023$ & $74.40 \pm 0.19$ & $76.60 \pm 0.23$ & $76.38 \pm 0.17$ & $23.61 \pm 0.17$ & $22.91 \pm 0.13$ \\
\hline & 40 & $1.23 \pm 0.10$ & $75.33 \pm 1.06$ & $76.73 \pm 1.00$ & $77.29 \pm 0.94$ & $22.70 \pm 0.94$ & $25.47 \pm 0.82$ \\
\hline & 60 & $1.08 \pm 0.07$ & $76.27 \pm 0.59$ & $76.34 \pm 1.04$ & $78.52 \pm 0.61$ & $21.47 \pm 0.61$ & $24.12 \pm 0.76$ \\
\hline
\end{tabular}

\section{AKNOWLEDGEMENTS}

The research is funded by the Polish Ministry of Science and Higher Education (2015-2019) under the Diamond Grant program nr. 0077/DIA/2015/14.

\section{REFERENCES}

Ahn S. Y., Eom S. Y., Rhie Y. H., Sung Y. M., Moon Ch. E. (2013). Application of refuse fuels in a direct carbon fuel cell system. Energy, vol. 51, 447-456. DOI: 10.1016/j.energy.2012.12.025.

Akdag A. S., Atimtay A., Sanin, F. D. (2016). Comparison of fuel value and combustion characteristics of two different RDF samples. Waste manage, vol. 47, 217-224. DOI: 10.1016/j.wasman.2015.08.037.

Bates R. B., Ghoniem A. F. (2012). Biomass torrefaction: Modeling of reaction thermochemistry. Bioresource technol, vol. 124, 460-469. DOI: 10.1016/j.biortech.2013.01.158.

Bergman P. C. A., Boersma A. R., Kiel J. H. A. (2004). Torrefaction for entrained-flow gasification of biomass. The 2 nd World Conference and Technology Exhibition on Biomass for Energy, Industry and Climate Protection, Roma, Italy 10-14.05.2004

Bergman P. C. A., Boersma A. R., Zwart R. W. R., Kiel J. H. A. (2005). Torrefaction of biomass exsiting coal-fired power stations. ECN publication ECN-C-05-013.

Białowiec A., Pulka J., Stępień P., Manczarski P., Gołaszewski J. (2017) The RDF/SRF torrefaction: An effect of temperature on characterization of the product - Carbonized Refuse Derived Fuel. Wastee manage, vol. 70, 91-100. DOI: 10.1016/j.wasman.2017.09.020.

Carrier M., Loppinet-Serani A., Denux D., Lasnier J.-M., Ham-Pichavant F., Cansell F., Aymonier C. (2011). Thermogravimetric analysis as a new method to determine the lignocellulosic composition of biomass. Biomass bioenergy, vol. 35, 298-307.

Çepolioğullar Ö., Haykiri-Açma H., Yaman S. (2016). Kinetic modeling of RDF pyrolysis: Model-fitting and model-free approaches. Waste manage, vol. 48, 275-284. DOI: 10.1016/j.wasman.2015.11.027.

Dalai A. K., Batta N., Eswaramoorthi I., Schoenau G. J. (2009) Gasification of refuse derived fuel in a fixed bed reactor for syngas production, Waste manage, vol. 29, 252-258.

Grammelis P., Basinas P., Malliopoulou A., Sakellaropoulos G. (2009). Pyrolysis kinetics and combustion characteristics of waste recovered fuels. Fuel, vol. 88. 195-205. DOI: 10.1016/j.fuel.2008.02.002.
Hryb W., Biegańska J. (2013). Wytwarzanie paliw z odpadów dla cementowni (Production of fuels from waste to cement plant). Przegląd komunalny, wydanie specjalne, n. 4, 50-59.

Kara M. (2012). Environmental and economic advantages associated with the use of RDF in Istanbul, Turkey. Waste Manage, vol. 29, 2976-2982.

Kordylewski W., Bulewicz E., Dyjakon A., Hardy T., Słupek S., Miller R., Wanik A. 2008. Spalanie i paliwa (Combustion and fuels). OWPW, Wrocław, ISBN 83-7085-912-7.

Kinitz N. (2014). Budujemy pełną parą. Raport. Spalarnie w Polsce (Construction at full speed, Raport, Polish incineration plants). Przegląd komunalny, n. 9.

Krawczyk P., Szczygieł J. (2013). Analiza uwarunkowań stosowania paliwa alternatywnego do wytwarzania energii elektrycznej i ciepław w warunkach przedsiębiorstwa ciepłowniczego (Analysis of the conditions for usingalternativefuels to generateelectricity and heat in a district heating company). Rynek Energii, n. 5, 91-96.

Kruger B., Mrotzek A., Wirtz S. (2014). Separation of harmful impurities from refuse derived fuels (RDF) by a fluidized bed. Waste manage, vol. 34, 390-401. DOI: 10.1016/j.wasman.2013.10.021.

Lu K. M., Lee, W. J. Chen W. H. Liu S. H., Lin T. C. (2012). Torrefaction and low temperature carbonization of oil pal fibre and eucalyptus in nitrogen and air atmospheres. Bioresource technol, vol. 123, 98105. DOI: 10.1016/j.biortech.2012.07.096.

Madanayake B. N., Gan S., Eastwick C., Ng H. K. (2016). Thermochemical and structural changes in Jatropha curcas seed cake during torrefaction for its use as coal co-firing feedstock. Energy, vol. 100, 262-272. DOI: 10.1016/j.energy.2016.01.097

Malińska K. (2015). Prawne i jakościowe aspekty dotyczące wymagań dla biowęgla (Legal and qualitative aspects of biocarbon requirements). Inżynieria i Ochrona Środowiska, vol. 18, n. 3, 359-371.

Malinowski M., Wolny-Koładka, K. (2015). Badanie procesu samonagrzewania się paliwa alternatywnego wytworzonego ze zmieszanych odpadów komunalnych (Investigation of the self heating process of analternativefuelderived from municipal solid waste). Proceedings of ECOpole, n. 9, 261-268. DOI: 10.2429/ proc.2015.9(1)034.

Manya J. J., Garcia-Ceballos F., Azuara M., Lotorre N., Royo C. (2015) Pyrolysis and char reactivity of poor-quality refuse-derived fuel (RDF) from municipal solid waste. Fuel process technol, vol. 140, 276-284. DOI: 10.1016/j.fuproc.2015.09.014. 
Miskolczi N., Borsodi N., Buyong F., Angyal A., Williams P.T. (2011). Production of pyrolytic oils by catalytic pyrolysis of Malaysia refuse-derived fuels in continuously stirred batch reactor. Fuel process technol, vol. 92, 925-932. DOI: 10.1016/j.fuproc.2010.12.012.

Nobre C., Goncalves M. M., Vilarinho C. G., Mendes B. S. (2016). Removal of Chromium and Aluminium from Aqueous Solutions Using Refure Derived Char. Technological Innovation for Cyber-Physical Systems. 7th IFIP WG 5.5/SOCOLNET Advanced Doctoral Conference on Computing, Electrical and Industrial Systems, DoCEIS 2016, Costa de Caparica, Portugal, April 11-13, 2016

Nowak M., Szul M. (2016). Possibilities for application of alternative fuels in Poland. Archives of waste management and environmental protection, vol. 18, 33-44.

Pietryszyn K., Primus A. (2015). Definition of the municipal waste in the context of the Renewable Energy Sources Act. Archives of waste management and environmental protection, vol. 17, 91-98.

PN-G-04513:1981 Standard. Solid fuels. Determination of the higher heating value and the lower heating value.

PN-G-04516:1998 Standard. Solid fuels. Determination of volatile content by means of the gravimetric method.

PN-EN 14346:2011 Standard. Waste characteristics. Calculation of dry mass on the basis of dry residue or water content.

PN-Z-15006:1993 Standard. Waste characteristics. Determination of morphological composition.

PN-Z-15008-04:1993 Standard. Municipal solid waste. Combustible and non-combustible content.

PN-EN 15169:2011 Standard. Waste characteristics. Content of organic matter.

Preston M., Kollberg P. (2016). Refused Derived Fuel (RDF) Project. European Union 8.09.2016.Robinson T., Bronson B., Gogolek P. Mehrani P. (2016). Sample preparation for thermo-gravimetric determination and thermo-gravimetric characterization of refuse derived fuel. Waste manage, vol. 48, 265-274. DOI: 10.1016/j.wasman.2015.11.018.
Sanchez-Silva L., López-González D., Villaseñor J., Sánchez P., Valverde J.L. (2012). Thermogravimetric-mass spectrometric analysis of lignocellulosic and marine biomass pyrolysis. Bioresour technol, vol. 109, 163-172.

Seo M. W., Kim S. D., Lee S. H., Lee J. G. (2010). Pyrolysis characteristics of coal and RDF blends in non-isothermal and isothermal conditions. J anal appl pyrol, vol. 88, n. 2, 160-167. DOI: 10.1016/j. jaap.2010.03.010.

Singh S., Wu Ch., Williams P. T. (2012). Pyrolysis of waste materials using TGA-MS and TGA-FTIR as complementary characterization techniques. J anal appl pyrol, vol. 94, 99-107. DOI: 10.1016/j. jaap.2011.11.011.

Soria-Verdugo A., Goos E., Gorcia-Hernando N. (2015). Effect of the number of TGA curves employed on the biomass pyrolysis kinetics results obtained using the Distributed Activation Energy Model. Fuel process technol, vol. 134, 360-371. DOI: 10.1016/j.fuproc.2015.02.018.

Stępień P., Pulka J., Serowik M., Białowiec A. (2017). Thermogravimetric and calorimetric characteristics of alternative fuel in terms of its use in low-temperature pyrolysis. Waste and Biomass Valorization. DOI: 10.1007/s12649-017-0169-6

Tummuluru J. S., Sokhansanj S., Wright Ch. T., Boardman R. D. (2010). Biomass torrefaction process review and moving bad torrefaction system model development. ASABE.

Tumuluru J. S., Sokhansanj S., Hess J. R., Wright Ch. T., Boardman R. D. (2011). A review on biomass torrefaction processand product properties for energy applications. Biotechnology, vol. 7, 384-401. DOI: 10.1089/ind.2011.7.384.

Whyte H. E., Whyte K. L., Awad S. Tazerout M. (2015). Pyrolytic oil production by calalytin of refuse-derived fuels: Investigation of low cost calalysts. Fuel process technol, vol. 140, 32-38. DOI: 10.1016/j.fuproc.2015.08.022. 